\title{
Osa-aika- ja päätoimitilojen tulot ja työnkäyttö
}

\author{
Maija Puurunen, Risto Seppälä \\ MTT Taloustutkimus (MTTL) Luutnantintie 13, 00410 Helsinki, \\ Maija.Puurunen@MTT.fi,.Risto.A.Seppala@MTT.fi
}

\section{Johdanto}

Viime vuosikymmen oli maatalousväestölle suurten muutosten aikaa. Maatalouden rakennekehitys on ollut suhteellisen nopeaa, tilojen lukumäärä on pudonnut ja samaan aikaan keskipeltoala on noussut usealla hehtaarilla (Tike 2002). Kuitenkin samanaikaisesti osa viljelijäperheistä hankkii lisätuloja harjoittamalla muita sivuelinkeinoja ja/tai käymällä töissä tilan ulkopuolella. Maatilayrityksien luokittelu yrityskoon ja toimialan huomioon ottavalla tavalla on sivuelinkeinojen, ulkopuolisten työssäkäyntien sekä yleensä toiminnan monipuolistumisen takia ongelmallista. Voidaankin todeta, että maataloudessa sovelletut nykyiset luokittelutavat eivät täysin vastaa niitä tarpeita, joita maataloussektorin rakennemuutoksen vaikutusten tarkastelu on tuonut mukanaan.

Maatiloja on usein tarkasteltu verotuksen tietoihin perustuvan Tilastokeskuksen Maatilatalouden yritys- ja tulotilaston pohjalta, johon on lisätty myös viljelijäpuolisoiden henkilöverotuksen tiedot (esim. Puurunen 1987, Väre 2000, Peltola 2000). Näiden tulotietojen perusteella tilat luokitellaan päätoimisiksi (maatilatalouden nettotulojen osuus vähintään $75 \%$ kaikista veronalaisista tuloista), sivuansiotiloiksi (nettotulojen osuus 50-75\%), osa-aikatiloiksi (25-50\%) ja vapaa-ajan tiloiksi (alle $25 \%$ ). Luokituksen perusteella päätoimisiksi tai osa-aikaisiksi luokiteltujen tilojen \%-jakauma on muuttunut jo pitkän aikaa ennen EU-jäsenyyttä siten, että päätoimitilojen osuus on vähentynyt ja "vapaa-ajan tilojen" osuus lisääntynyt. Viimeaikaisen maatalouden rakennekehityksen seurauksena päätoimitilojen lukumäärä ei ole kuitenkaan vähentynyt yhtä nopeasti kuin paljon pieniä tiloja sisältäneiden osa-aikaja vapaa-ajan tilojen lukumäärä (Peltola 2000).

Tämän kehityksen takaa löytyy useita selittäviä tekijöitä, mutta eräs merkittävimmistä lienee perinteisen maataloustuotannon epävarmuustekijät ja siitä johtuvat riskit, joita alkutuotanto viljelijäperheen ainoana tulolähteenä aiheuttaa (Peltola 2000). Tilan ulkopuoliset lisäansiot kuin myös tuotannon laajentaminen edellyttävät useimmiten myös työpanoksen lisäämistä. Tämä tarkoittaa joko viljelijäperheen työpanoksen uudelleen kohdentamista, lisäämistä tai palkatun työvoiman käyttöä. Koska pääoma ja työ ovat toisiaan korvaavia panoksia, osa työpanoksenlisätarpeesta on maataloudessa yrityskoon kasvun yhteydessä korvattu pääomalla. Toisaalta työn tuottavuus ei kuitenkaan ole noussut EUjäsenyyden aikana niin paljoa, etteikö viljelijäperhe tulotasonsa säilyttämiseksi joutuisi jossain määrin lisäämään myös työnkäyttöä. Tähän viittaavat mm. Myyrän ja Pietolan $(1999,2002)$ tutkimukset tuottavuuden kehityksestä. Tutkimuksessa ja sen päivityksessä todetaan, että Suomen maatalouden tuottavuuskehitys on ollut koko 1990-luvun ja vielä vuosina 2000-2001 erittäin hidasta, jopa pysähdyksissä. Vuosina 2000-2001 maataloudessa saatiin samalla panosmäärällä aikaan noin 13,9 \% enemmän tuotantoa kuin vuonna 1992. Vuosina 1995-2000 maitotilojen tuotannon määrä nousi 1,3 kertaiseksi, sikatilojen 1,7 kertaiseksi, mutta viljatilojen tuotannon määrä laski, eli vastaavasti vuonna 2000 se oli 0,97 -kertainen (Myyrä ja Pietola 1999, 2002).

Tämän osa-aika- ja päätoimitiloja koskevan tutkimuksen tarkoituksena on tuottaa tietoa ja mahdollisia käytännön sovelluksia maatalouden verotusaineistojen ja rakennetilastojen tietojen hyödyntämiseksi viljelijäväestön tulonmuodostuksen ja tulotason muutoksen seurannassa. Erityisenä kiinnostuksen kohteena ovat maatalouteen voimakkaasti investoineet päätoimiset tilat ja toisaalta myös maatalouden osa-aikaistuminen. Tutkimuksen tavoitteiden saavuttamiseksi laaditaan osa-aikaisuuden ja päätoimisuuden luokitteluun uusi aineistolähtöinen luokittelutapa soveltamalla tulo- ja työnkäyttötietoja. Uudella luokittelulla pyritään korvaamaan aiemmissa tutkimuksissa yleisesti käytettyä tuloosuuksiin perustuvaa luokitusta. 


\section{Aineisto ja menetelmät}

Tutkimusaineisto koottiin liittämällä yhteen vuoden 2000 Tilastokeskuksen Maatilatalouden yritys- ja tulotilaston (MYTT) otostilojen aineisto ja näiden tilojen viljelijäpuolisoiden henkilöverotuksen tiedot sekä kyseisiä tiloja koskevat työvoiman käyttötiedot Tiken vuoden 2000 maatalouslaskennan tiedoista.

MYTT:n tiedot perustuvat pääosin maa- ja metsätalouden verolomakkeisiin ja ne sisältävät verotuksen mukaiset tiedot maatilojen tuloista, menoista, koroista, omaisuudesta ja veloista. Mukana on myös taustatietoa tilan eläinmääristä ja pinta-aloista. Tiedot on kerätty ositetulla satunnaisotannalla otokseen valituilta noin 9000 luonnollisen henkilön hallinnassa olevalta maatilalta (Tilastokeskus 2003). Henkilöverotuksen tiedoista ilmenee MYTT:n maatilatalouden tulojen lisäksi myös viljelijäpuolisoiden muut yrittäjätulot, ansiotulot, omaisuustulot sekä eläketulot. Näiden tulotietojen perusteella selvitetään näiltä tiloilta viljelijäpuolisoiden tulojen jakautuminen eri lähteisiin.

Maatalouslaskennan työvoimankäyttötiedoissa (TIKE 2001) on tilalla vuodessa maataloustöihin käytetty aika ilmaistuna työaikaluokittain viljelijäpuolisoilta, muilta perheenjäseniltä ja palkatulta työvoimalta. Lisäksi tiedoista käy ilmi lyhytaikaisen työvoiman, urakoitsijoiden ja lomittajien tekemien työpäivien määrä sekä tieto viljelijäpuolisoiden työssäkäynnistä tilan ulkopuolella.

Maatalouden pää- ja sivutoimisuutta on tutkimuksissa tarkasteltu monella eri tavalla. Peltola (2000) esittää tutkimuksessaan laajan katsauksen pää- ja sivutoimisuuden (monitoimisuuden) käsitteisiin ja niiden luokitteluun. Yleisimmät luokittelutavat perustuvat tulojen ja/tai työajan jakautumisesta eri tulolähteisiin. Koska työajan käytöstä on harvoin olemassa tietoja, perustuvat sovellettavat luokittelut käytännössä useimmiten pelkästään tulotietoihin. Suomessa käytetään usein Tilastokeskuksen Maatilatalouden tulo- ja verotilaston mukaista luokittelua (esim. Väre 2000). EU:n yhteisessä FADN kirjanpitotilajärjestelmässä luokitellaan maatilayritykset taloudellista tilakokoa kuvaavan mittarin, laskennallisen vakiokatekertymän (SGM), mukaan ja tilojen päätoimisuus määrittyy maittain valitun SGM-alarajan perusteella (Tiainen ja Katajamäki 1996).

Tässä tutkimuksessa yhdistettyä aineistoa käsitellään faktori ja ryhmittely- eli klusterianalyysein (Mustonen 1995). Faktorianalyysillä pyritään löytämään havaitun aineiston taustalla piilevästi vaikuttavat taustamuuttujat, faktorit. Klusterianalyysillä taas muodostetaan samankaltaisten havaintojen ryhmiä. Tavoitteena on muodostaa aidosti päätoimisten viljelijöiden ryhmä, joissa sekä tulo- että työpanostiedot viittaavat viljelijäpuolisoiden päätoimisuuteen tilalla, ja toisaalta taas vastaavasti eri tavoin osa-aikaisten tilojen ryhmiä. Ryhmittelevinä muuttujina käytetään verotus-, työpanos- ja muista tilan taustatiedoista faktorianalyysillä muodostettujen taustamuuttujien arvoja, faktoripistemääriä. Faktoripistemäärien käytöllä ryhmittelyssä saavutetaan eräitä etuja alkuperäisen aineiston käyttöön verrattuna. Faktoripistemäärät ovat normitettuja vakio varianssiin 1, jolloin alkuperäisten muuttujien varianssien erot eivät häiritse analyysiä. Lisäksi muuttujissa mahdollisesti olevat mittavirheet saadaan suodatettua pois aineistosta (Mustonen 1995, Ranta ym. 1994).

Tutkimuksessa myös osittain päivitetään viljelijäväestön tulokehityksen kuvaus vuoteen 2000 asti tilojen päätoimisuuden mukaan MTT Taloustutkimuksessa aiemmin käytetyillä Tilastokeskuksen ryhmittelyillä (Väre 2000) joka esitettiin artikkelin alussa. Täten päästään vertailemaan eri luokitustapojen aiheuttamia eroja tulorakenteessa. Monimuuttujamenetelmien tuloksena saaduissa tilaryhmissä tavoitteena on myös selvittää maataloustukien merkitystä niiden tulomuodostuksessa sekä yleensäkin kartoittaa viljelijäväestön tulotasoa ja arvioida sen kehitystä. Samalla pyritään tunnistamaan tulonmuodostuksen ja tulokehityksen osalta mahdolliset ongelmatilaryhmät. Tulosten tarkastelu näiltä osin on viljelijäpuolisoiden koko tulonmuodostuksen huomioon ottava.

\section{Tulokset ja tulosten tarkastelu,}

Tulo-osuuteen perustuvan luokituksen mukaan tarkasteltuna vuonna 1995 päätoimitiloja ja vapaa-ajan tiloja oli suunnilleen yhtä paljon eli $35 \%$ tiloista, mutta vuonna 2000 päätoimitiloja oli $37 \%$ ja vapaaajan tiloja $32 \%$ tiloista. Kehitys näyttäisi viittaavan siihen, että vapaa-ajan tiloilla ollaan luopumassa maatalouden harjoittamisesta kokonaan ja poistumassa maatalouden verotukseen liittyvän tilastoinnin piiristä palkkatyöhön muille elinkeinosektoreille tai tuotanto on muodostumassa päätoimisemmaksi. Osa-aika- ja sivuansiotilojen osuuden hienoinen lisääntyminen tilajakaumassa viittaa osaltaan sivuansioiden lisääntymiseen maatalouden ohessa, mutta osin myös maatalouden tulotuista johtuen maatalouden tulo-osuus näillä tiloilla on muodostunut aiempaa suuremmaksi. Tämä ei kuitenkaan kumoa Peltolan (2000) toteamusta siitä, että lisätulojen hankkiminen alkutuotannon ulkopuolelta on tulevaisuudessa edelleen lisääntymässä. Päätoimitilojen osuuden lisääntyminen tilajakaumassa viittaa osal- 
taan maatalouden viimeaikaiseen rakennekehitykseen eli keskikokoisille ja sitä suuremmille tiloille suunnattujen investointitukien ja tilakoon kasvun kautta laajentuneeseen päätoimiseen maataloustuotantoon.

Vaihtoehtoisen luokittelun luomiseksi lähtöaineistojen kokonaistilamäärästä tutkimukseen rajattiin mukaan maatilat jotka ovat yksityisen henkilön omistamia ja joiden työvoimankäyttötiedot on ilmoitettu maatalouslaskennassa perheviljelmä luokassa. Ehdot täyttäviä tiloja löytyi aineistoista 7906 kappaletta. Faktoroinnissa ja ryhmittelyssä aineistoa käsiteltiin yhtenä kokonaisuutena erittelemättä sitä alueellisesti tai tuotantosuunnittain. Taloustutkimuksen kirjanpitotila-aineistolla tehdyn esitutkimuksen ja tutkimusaineiston alustavien tulosten perusteella oletettiin aineistosta kuitenkin muodostuvan eri tulolähteitä kuvaavat faktorit. Analysoitaessa vertailtiin eri faktorimäärien tuottamia tuloksia: faktoreiden tulkittavuutta, kunkin faktorin osuutta aineiston vaihtelun selittämisessä ja kokonaisselitysastetta.

Arvioinnissa päädyttiin pitämään parhaana 12 faktorin muodostamaa tulosta, jolloin muodostuneet faktorit selittävät $43 \%$ aineiston vaihtelusta. Muodostuneiden faktoreiden voitiin odotusten mukaisesti tulkita edustavan eri tulolähteitä: maidontuotantoa, viljantuotantoa, sianlihantuotantoa, siipikarjataloutta, puutarhatuotantoa, metsätaloutta, naudanlihantuotantoa, porsastuotantoa, sokerijuurikkaan tuotantoa, palkkatuloja, perunantuotantoa ja muuta elinkeinotoimintaa.

Faktoreiden tilakohtaisia arvoja, faktoripistemääriä, käytettiin tilojen ominaisuuksia kuvaavina muuttujina ryhmittelyanalyysissä. Ryhmittelyanalyysissä kukin tila ensin sijoitettiin sitä lähinnä olevan, ennalta valitun, ryhmäkeskipisteen edustamaan ryhmään. Tämän jälkeen ryhmänkeskipiste päivitettiin edustamaan muodostunutta ryhmää ja tilojen sijoittelu ryhmiin toistettiin uusien keskipisteiden mukaisesti. Tätä toistetaan kunnes ryhmäkeskipisteiden paikat eivät enää muutu (K-means algoritmi). Tulokset ovat riippuvaisia lähtötilanteessa valituista ryhmäkeskipisteistä ja ryhmien muodostumista voi ohjailla rajoittamalla eri tavoin keskipisteiden muodostumista. Myös hierarkista, suoraan lähimmät ryhmät/havainnot yhdistävää ryhmitystapaa kokeiltiin, mutta se ei antanut yhtä selkeitä tuloksia kuin em. menetelmä.

Muodostettavien ryhmien määrän arvioitiin alustavasti olevan MYTT:n tuotantosuuntien määrää (12 kpl) selvästi suurempi. Lisäksi apuna käytettiin myös Pseudo F ja CCC (Cubic Clustering Criterion) testikriteerejä (esim. Peltola 2000). Aineisto päädyttiin jakamaan 22 ryhmään.

Tarkasteltavien muuttujien ryhmäkohtaisten keskiarvojen perusteella ryhmittelyssä muodostui selvästi erilaisia tilaryhmiä. Maataloudenmyyntitulojen perusteella muodostui kaksi ryhmää, jotka saavat huomattavan paljon myyntituloja sika- tai siipikarjataloudesta. Tuloksista erottui myös kolme selvästi muita ryhmiä vähemmän myyntituloja saavaa ryhmää. Myyntitulojen määrää verrattiin ryhmän tilojen MYTT:n ja maatilarekisterin mukaisiin tuotantosuunnan määritelyyn. Tällöin havaittiin suuria myyntituloja saavien tilaryhmien sisältävän vain muutamaa tuotantosuuntaa kun taas vähän myyntituloja saavissa ryhmissä oli useita eri tuotantosuuntia.

Ryhmien pää- ja sivutoimisuuden arvioimiseksi tarkasteltiin ryhmien tulojen jakautumista eri lähteisiin ja työajan käyttöä. Tulosten perusteella paljon maatalouden myyntituloja saavien ryhmien voitiin odotusten mukaisesti katsoa muodostuneen päätoimisista tiloista. Vähän maatalouden myyntituloja saavien ryhmien tiloja ei kuitenkaan voitu suoraan luokitella ei-päätoimisiksi, sillä kaksi vähiten myyntituloja saanutta ryhmää poikkesivat selvästi toisistaan tulorakenteeltaan ja työajan käytöltään.

Ensimmäisessä näistä ryhmistä palkkatulot olivat selvästi suurin tulonlähde. Työaikatietojen mukaan tässä ryhmässä tilan ulkopuolella työssäkäynti oli yleisintä ja maataloustöihin käytetty työaika vähäisintä verrattuna muihin ryhmiin. Edellisen vastakohtana toisessa ryhmässä muiden tulonlähteiden osuus oli maataloutta pienempää, maataloustöissä käytettiin keskimäärin enemmän aikaa ja tilan ulkopuolella työssäkäynti oli lähellä aineiston keskimääräistä tasoa. Tässä ryhmässä oli lisäksi eläimiä kolminkertaisesti ensimmäiseen ryhmään verrattuna.

Tulosten perusteella nähdään myös muodostuneen metsätaloutta harjoittavien tilojen ryhmä sekä kaksi muuta elinkeinotoimintaa harjottavien tilojen ryhmää.

Tilastokeskuksen tulo-osuus luokitukseen verrattuna ei mikään ryhmä muodostetussa ryhmityksessä täysin puhtaasti vastaa tulo-osuus luokitusta, mutta luokitus antaa kuitenkin ryhmien tulonmuodostuksen ja työnkäytön perusteella määritettyyn päätoimisuuden asteeseen nähden samansuuntaisen tuloksen. 


\section{Johtopäätökset}

Tässä verotusaineistoihin perustuvassa tutkimuksessa näkökulma on viljelijöiden tulonmuodostuksessa ja taloudellisessa toimeentulossa. Sitä vastoin maatalouden kannattavuuden tarkasteluun edes työpanostiedoilla täydennetyt verotustiedot eivät ole riittävät. Kannattavuuden tarkasteleminen edellyttää tilan tasetietoja ja se on nykyisin mahdollista ainoastaan MTT Taloustutkimuksen kannattavuuskirjanpidon tulosten pohjalta, jotka kuitenkin edustavat suhteellisen päätoimisia maatiloja.

Viljelijäväestön tulonmuodostuksella, koskee se sitten päätoimista maataloudenharjoittamista tai pääosin maatalouden ulkopuolella toimimista, on laajat vaikutukset maaseudun elinvoimaisuuteen. Tutkimuksessa käytettyjen ryhmittelyjen laajentaminen alueittaisella luokituksella mahdollistaisi huomion kiinnittämisen osa-aikatilojen ja maatalouden ulkopuolisten tulojen merkitykseen osana maaseutuyhteisön taloudellista toimeentuloa ja maaseudun elinvoimaisuutta maan eri osissa.

Tulosten perusteella voidaan sanoa monimuuttujamenetelmien soveltuvan maatilojen luokitteluun toiminnan osa-aikaisuuden ja päätoimisuuden suhteen ja pystyvän tuottamaan luokituksen huomioiden samanaikaisesti usean eri muuttujan vaikutuksen. Hyvän ryhmityksen muodostaminen monimuuttujamenetelmiä soveltamalla vaatii kuitenkin harkintaa, koska menetelmät eivät anna yhtä oikeaa tulosta. Pikemminkin tuloksena on valikoima eri oletuksilla saatuja vaihtoehtoja, joiden vertailuun ei ole olemassa helppoa ja yksinkertaista arviointikriteeriä.

\section{Kirjallisuus}

Mustonen, S. 1995. Tilastolliset monimuuttujamenetelmät. Helsingin yliopisto. Tilastotieteen laitos. Survo Systems Oy. Helsinki. $205 \mathrm{~s}$.

Myyrä, S. \& Pietola, K. 1999. Tuottavuuskehitys Suomen maataloudessa vuosina 1987-97. Maatalouden taloudellisen tutkimuslaitoksen tutkimuksia 234. Helsinki. $57 \mathrm{~s}$.

Myyrä, S. \& Pietola, K. 2002. Maatalouden kokonaistuottavuuden kehitys. Työpaperi. MTT taloustutkimus. Helsinki. $15 \mathrm{~s}$.

Peltola, A. 2000. Viljelijäperheiden monitoimisuus suomalaisilla tiloilla. Maatalouden taloudellisen tutkimuslaitoksen julkaisuja 96. Helsinki. $280 \mathrm{~s}$.

Puurunen, M. 1987. Viljelijäväestön tulojen vertaaminen muiden väestöryhmien tuloihin. Maatalouden taloudellisen tutkimuslaitoksen tiedonantoja 134. Helsinki. $171 \mathrm{~s}$.

Ranta, E., Rita, H. \& Kouki, J. 1994. Biometria Tilastotiedettä ekologeille. Viides painos. Helsinki. 569 s.

Tiainen, S. \& Katajamäki, E. 1996. EU:n Maatilatypologia Suomessa. Maatalouden taloudellisen tutkimuslaitoksen tiedonantoja 209. Helsinki. $81 \mathrm{~s}$.

TIKE 2002. Maatilatilastollinen vuosikirja 2002. SVT. Maa-, metsä- ja metsätalous 2002:65 Maa- ja metsätalousministeriön tietopalvelukeskus. Helsinki. $267 \mathrm{~s}$.

TIKE 2001. Maatalouslaskenta 2000 Maatalouden työvoima. Julkaisu 2001:2 Maa- ja metsätalousministeriön tietopalvelukeskus. Helsinki. $36 \mathrm{~s}$.

Tilastokeskus. 2003. Maatilatalouden yritys- ja tulotilasto 2000. SVT. Maa-, metsä- ja kalatalous 2003:51 Tilastokeskus. Helsinki. $66 \mathrm{~s}$.

Väre, M. 2000. Viljelijöiden tulotasovertailu. Maatalouden taloudellisen tutkimuslaitoksen tutkimuksia 242. Helsinki. $168 \mathrm{~s}$. 